\title{
A polymorphism in the interleukin-4 receptor affects the ability of interleukin-4 to regulate Th17 cells: a possible immunoregulatory mechanism for genetic control of the severity of rheumatoid arthritis
}

Susan K Wallis, Laura A Cooney, Judith L Endres, Min Jie Lee, Jennifer Ryu, Emily C Somers, David A Fox*

\begin{abstract}
Introduction: Rheumatoid arthritis (RA) is now suspected to be driven by pathogenic Th17 cells that secrete interleukin (IL)-17 and can be regulated by IL-4. A single-nucleotide polymorphism (SNP), I50V, in the coding region of the human IL-4 receptor (IL-4R) is associated with rapid development of erosive disease in RA. The present study was undertaken to determine whether this SNP renders the IL-4R less able to transduce signals that regulate IL-17 production.
\end{abstract}

Methods: Peripheral blood mononuclear cells were activated under Th17-stimulating conditions in the presence or absence of IL-4, and IL-17 production was measured by both enzyme-linked immunosorbent assay (ELISA) and flow cytometry. Serum IL-17 was also measured by ELISA. Paired comparisons were performed using the two-tailed ttest. IL-4 receptor gene alleles were determined by polymerase chain reaction.

Results: In healthy individuals, IL-4 significantly inhibited IL-17 production by cells from subjects with the I/I genotype $(P=0.0079)$ and the IN genotype $(P=0.013)$, but not the $V / N$ genotype $(P>0.05)$. In a cross-sectional sample of patients with established RA, the magnitude of the in vitro effect of IL-4 was lower and was not associated with a specific IL-4R allele. Serum IL-17 levels were higher in RA patients than in healthy individuals, as was the percentage of $\mathrm{CD}^{+}$cells that produced IL-17.

Conclusions: These results indicate that an inherited polymorphism of the $I L-4 R$ controls the ability of the human immune system to regulate the magnitude of IL-17 production. However, in established RA, this pattern may be altered, possibly due to secondary effects of both RA itself as well as immunomodulatory medications. Ineffective control of Th17 immune responses is a potential mechanism to explain why IL-4R is an important severity gene in RA, but this issue will require careful study of a cohort of new-onset RA patients.

\section{Introduction}

Until recently, $\mathrm{CD} 4^{+}$lymphocytes were thought to contain two distinct lineages of effector cells, the Th1 and Th2 subsets that are defined by secretion of either interferon (IFN)- $\gamma$ or interleukin (IL)-4. This paradigm has been modified to now include a third $\mathrm{CD} 4^{+} \mathrm{T}$-cell

\footnotetext{
* Correspondence: dfox@umich.edu
Division of Rheumatology and Rheumatic Diseases Research Core Center,

* Correspondence: dfox@umich.edu
Division of Rheumatology and Rheumatic Diseases Research Core Center, Department of Internal Medicine, University of Michigan, 1500 East Medical Center Drive, Ann Arbor, MI 48109, USA
}

(c) 2011 Wallis et al.; licensee BioMed Central Ltd. This is an open access article distributed under the terms of the Creative Commons Attribution License (http://creativecommons.org/licenses/by/2.0), which permits unrestricted use, distribution, and reproduction in any medium, provided the original work is properly cited.

population, the Th17 cells $[1,2]$. Th17 cells are critical for autoimmune inflammation in a variety of murine models of human disease, such as experimental autoimmune encephalomyelitis (EAE) and collagen-induced arthritis (CIA) [3-5].

Unique mechanisms control the development of these cells. The cytokines IL- 6 and tumor growth factor (TGF) $\beta$ are crucial for the generation of Th17 cells in the mouse [6-8], while IL-1 $\beta$, IL-6 and IL-23 induce and maintain the differentiation of human Th17 cells $[9,10]$. 
Accumulating evidence suggests that Th17 cells play a central role in the development of human autoimmune diseases, including RA, inflammatory bowel disease and multiple sclerosis [11].

Th17 cell development and cytokine secretion are downregulated in vitro by IFN- $\gamma$ and IL-4 produced by Th1 and Th2 cells, respectively $[1,2,12,13]$. Understanding the mechanisms of Th17 regulation in human disease is essential for the development of novel, targeted therapies and to guide therapeutic decision-making.

Several findings suggest that the Th2 cytokine IL- 4 and its receptor may be of particular interest in the control of Th17-induced inflammation. In mice, the genetic absence of IL-4 leads to more severe arthritis in the CIA model [14]. Conversely, dendritic cells transfected with a retroviral vector that drives expression of IL-4 reduced the severity of CIA and suppressed IL-17 production in secondary responses to type II collagen $[15,16]$. Suppression of IL-17 production by type II collagen-specific T cells was seen early in CIA, but $\mathrm{T}$ cells from established late CIA were refractory to inhibition of IL-17 production by IL-4 [16]. Exosomes derived from IL-4-expressing dendritic cells were also found to be therapeutic in CIA [17].

In humans, a diminished response to IL-4 is thought to contribute to autoimmune inflammation [18]. A single-nucleotide polymorphism (SNP) in the coding region of the $I L-4 R$ governs the presence of isoleucine (I) versus valine $(\mathrm{V})$ at position 50 in the amino acid sequence. This polymorphism in $I L-4 R$ is functionally important because it affects the strength of signaling through the receptor $[19,20]$.

Additional evidence for a crucial role of IL-4 in regulating human RA comes from a report of the effect of IL-4 receptor gene $(I L-4 R)$ polymorphisms on the course and severity of RA. Prots et al. [21] studied the role of two $I L-4 R$ SNPs in RA susceptibility and severity in a cohort of controls and RA patients with erosive disease. In their study, each polymorphism was in HardyWeinberg equilibrium, and $I L-4 R$ was not found to be an RA susceptibility gene. The I50 and V50 alleles were in an approximately 1:1 ratio in both the RA and control groups. Two years after the onset of disease $68 \%$ of RA patients homozygous for the V50 allele had radiographically visible bone erosion compared to $37 \%$ of the patients homozygous for the I50 allele. Heterozygotes had an intermediate level of radiographic severity. The V50 homozygous patients demonstrated weaker signaling through the IL-4R as measured by GATA-3 transcription and IL-12R expression in cultured T cells [21]. A second polymorphism, located elsewhere in $I L-4 R$, did not control RA severity. These findings suggest that a unique $I L-4 R$ polymorphism may predict disease outcome in RA. Since tight control of the clinical activity of
RA substantially improves patient outcomes [22,23], identification of patients who require early aggressive treatment by genotyping for severity has the potential to enhance patient care.

On the basis of these considerations, we hypothesized that a hypofunctional IL-4R would allow unchecked Th17 differentiation and Th17-driven inflammation. We sought to show that Th17 cells derived from healthy V50 homozygotes would be less susceptible to suppression of IL-17 production by IL-4 compared to I50 homozygotes or heterozygotes. We also undertook a pilot cross-sectional study of patients with established RA to assess the relationship between $I L-4 R$ genotype, disease activity and regulation of IL-17 production in vivo and in vitro. Our data indicate that deficiency in regulation of IL-17 production is a possible mechanism to explain the association of an $I L-4 R$ polymorphism with RA severity.

\section{Materials and methods}

\section{Study populations and clinical evaluation}

Twenty patients with established RA and 26 healthy individuals were enrolled in the study. The average age of the healthy individuals was 40.6 years (range, 21 to 62 years), and this group included 12 females and 14 males. The characteristics of the RA patients are summarized in Table S1 (Additional file 1). Health assessment questionnaires were completed by each patient, and disease activity scores were calculated on the basis of a 28-joint count and a visual analogue scale. Thirty milliliters of blood were collected from each subject. Twenty milliliters were saved for cell culture, $5 \mathrm{ml}$ were saved for DNA isolation and genotyping and $5 \mathrm{ml}$ were saved for serum. All study participants provided written informed consent. The research protocol was approved by the University of Michigan Institutional Review Board.

\section{DNA isolation and genotyping}

DNA was isolated from peripheral blood cells using the Qiagen QIAmp Blood Midi kit (Qiagen, Chatsworth, CA, USA) by a spin protocol according to manufacturer's instructions. Genotypes for I50V SNP of the $I L-4 R$ were determined by allele-specific real-time polymerase chain reaction (RT-PCR) using TaqMan Genotyping Assays (Applied Biosystems, division of Life Technologies, Carlsbad, CA, USA). The National Center for Biotechnology Information SNP reference for the I50V allele is rs1805010, and the nucleotide sequence surrounding the probe is CTGTGTCTGCAGAGCCCACACG TGT[A/G] TCCCTGAG AACAACGGAGGCGCGGG. RT-PCR was performed for allelic discrimination using a quantitative fluorescence measurement system. 


\section{Cell culture}

Peripheral blood mononuclear cells (PBMCs) were isolated from heparinized peripheral whole blood of RA patients and healthy controls by gradient centrifugation over Histopaque-1077 (Sigma, St. Louis, MO, USA). Cell cultures were performed in RPMI 1066 medium (Lonza, Basel, Switzerland) with $10 \%$ fetal bovine serum, $1 \%$ penicillin G/1\% streptomycin and 2\% L-glutamine. PBMCs were activated with Orthoclone OKT3 (anti-CD3, produced in the University of Michigan Hybridoma Core) $1 \mu \mathrm{g} / \mathrm{ml}$ and either Th17-stimulating conditions alone (IL-23, $10 \mathrm{ng} / \mathrm{ml}$; IL-1 $\beta, 5 \mathrm{ng} / \mathrm{ml}$; IL-6, $10 \mathrm{ng} / \mathrm{ml}$ ) or Th17-stimulating conditions with the addition of IL-4 $(50 \mathrm{ng} / \mathrm{ml})$. Cells were left in culture for 96 hours. Supernatants were collected from each culture condition and stored at $-80^{\circ} \mathrm{C}$ for analysis by ELISA.

\section{Surface and intracellular staining}

On day 5 of culture, the cells were restimulated with phorbol myristate acetate $(5 \mathrm{ng} / \mathrm{ml})$ and ionomycin $(500 \mathrm{ng} / \mathrm{ml})$ for 1 hour prior to addition of brefeldin A $(10 \mu \mathrm{g} / \mathrm{ml})$ for 5 more hours. The cells were washed and $1 \times 10^{6}$ cells per sample were used for staining. Cells were first blocked with $20 \mu \mathrm{l}$ of $10 \%$ human serum/10\% mouse serum in PBS at $4^{\circ} \mathrm{C}$ for 15 minutes. The cells were surface-stained with antigen-presenting cell (APC)labeled mouse anti-human CD4 (BD Bioscience (Palo Alto, CA, USA) or APC-conjugated mouse immunoglobulin $\mathrm{G}_{1}\left(\mathrm{mIgG}_{1}\right)$ isotype control (Ebioscience, San Diego, CA, USA), at $4^{\circ} \mathrm{C}$ for 30 minutes, washed twice with cold $2 \%$ newborn calf serum/phosphate-buffered saline (NCS/PBS) buffer and fixed overnight in $4 \%$ paraformaldehyde. The cells were then permeabilized with $0.5 \%$ saponin in $2 \% \mathrm{NCS} / \mathrm{PBS}$. Intracellular cytokine staining was performed using fluorescein isothiocyanate (FITC)-labeled anti-human IFN- $\gamma$ (BD Bioscience) and phycoerythrin (PE)-labeled anti-human IL-17A (Ebioscience), or FITC-conjugated $\mathrm{mIgG}_{1}$ isotype control (Ebioscience) and PE-conjugated mouse IgG $_{1}$ isotype control (Ancell, Bayport, MN, USA). Samples were run on a BD Biosciences FACS Calibur flow cytometer and analyzed by CellQuest Pro (BD Bioscience).

\section{ELISA}

Both culture supernatants and fresh sera were analyzed by ELISA for IL-17A levels. Flat-bottomed, high binding, 96-well plates (Corning Costar, Lowell, MA, USA) were coated overnight at $4^{\circ} \mathrm{C}$ with anti-human IL-17-purified antibody (Ebioscience) diluted to 1:500 with $0.1 \mathrm{M}$ carbonate buffer, $\mathrm{pH}$ 9.4. On day 2, the plates were washed three times with $1 \times \mathrm{PBS} / 0.05 \%$ Tween at $200 \mu \mathrm{l}$ per well and blocked using $200 \mu \mathrm{l}$ of PBS with $10 \%$ fetal calf serum per well for 2 hours. The plates were then washed three times with $200 \mu \mathrm{l}$ of $1 \times \mathrm{PBS} / 0.05 \%$
Tween per well. The standard curve was created in duplicate starting with a concentration of $2,000 \mathrm{pg} / \mathrm{ml}$ and serial twofold dilutions to $7.8 \mathrm{pg} / \mathrm{ml}$. Supernatants and sera were assayed in triplicate at $100 \mu \mathrm{l}$ per well, both undiluted and at a 1:5 dilution. The samples were then refrigerated at $4^{\circ} \mathrm{C}$ overnight, after which they were washed five times with $200 \mu \mathrm{l}$ of $1 \times \mathrm{PBS} / 0.05 \%$ Tween per well. A secondary biotinylated anti-IL-17 antibody and the detection reagent streptavidin horseradish peroxidase were added to each well and incubated at room temperature for 2 hours. The plates were washed seven times with $1 \times \mathrm{PBS} / 0.05 \%$ Tween with 1 -minute soaks between washes. Tetramethylbenzidine $100 \mu$ l were added to each well, and plates were kept in the dark at room temperature for 10 to 30 minutes. Stop solution, $2 \mathrm{~N} \mathrm{H}_{2} \mathrm{SO}_{4}$, was added to each well. ELISA plates were read by a Synergy HT plate reader (Biotek, Winsooki, VT, USA) and analyzed by KC4 software (Biotek).

\section{Statistical analysis}

The data were analyzed with GraphPad Prism version 4.02 software (GraphPad Software Inc., San Diego, CA, USA). Paired comparisons were performed using a twotailed $t$-test. Values of $P \leq 0.05$ were considered significant. Dot plots were generated in CellQuest Pro.

\section{Results}

\section{IL-17 production in culture supernatants}

We measured IL-17 secretion by ELISA of lymphocyte culture supernatants. In the healthy individuals there was a significant increase in the IL-17 level after the addition of Th17-stimulatory cytokines over baseline T cell stimulation with anti-CD3 $(P<0.01)$, and there was a significant decrease in the measured IL-17 level with the addition of IL-4 to the Th17-stimulatory conditions (Figure 1).

We then further examined these groups by specific genotype. In the I/I genotype group, addition of IL-4 led to a significant reduction in IL-17 production by cells that had been stimulated under Th17 conditions $(P<$ $0.01)$. There was also a significant reduction in IL-17 production after the addition of IL-4 to cells from the I/ $\mathrm{V}$ genotype group $(P<0.05)$. However, IL- 4 was unable to significantly reduce IL-17 production in cell cultures from the $\mathrm{V} / \mathrm{V}$ genotype group when the data were analyzed using paired comparisons (Figure 2A and 2B).

\section{Cross-sectional pilot study of RA patients}

Of the 20 RA patients ( $85 \%$ women and $15 \%$ men), 4 were homozygous for isoleucine, 6 were heterozygous and 10 were homozygous for valine at amino acid 50 of the IL-4R (Table S1 in Additional file 1). The mean disease activity score (DAS) for the patients with an I/I genotype was 3.1, representing low disease activity. 


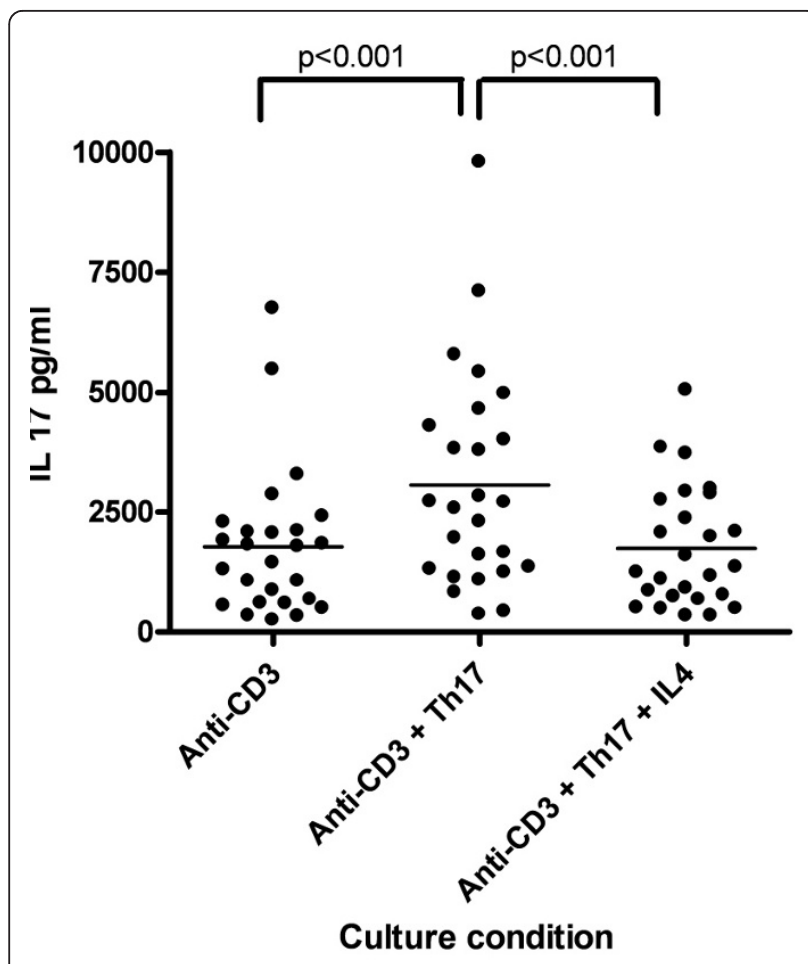

Figure 1 Regulation of interleukin (IL)-17 production in vitro. IL$17 \mathrm{~A}$ levels $(\mathrm{pg} / \mathrm{ml})$ measured by enzyme-linked immunosorbent assay (ELISA) from supernatants taken from three different culture conditions in healthy individuals. Calculated $P$ values are from twotailed $t$-tests between IL-17 levels measured by ELISA from cultures containing anti-CD3, anti-CD3 plus Th17 stimulatory conditions and anti-CD3 plus Th17 stimulatory conditions with the addition of IL-4.

The mean DAS for the patients with the I/V genotype was 3.9, or moderate disease activity, and for the patients with the $\mathrm{V} / \mathrm{V}$ genotype the mean DAS was 4.2 , or high to moderate disease activity. The differences between these groups were not statistically significant, but suggest a trend toward association of the $\mathrm{V}$ allele with more active disease, notwithstanding the aggressive treatment that these patients were receiving.

There was not a significant increase in IL-17 production in RA patients in Th17-skewing conditions versus culture with anti-CD3 alone $(P=0.13)$ (Figure $\mathrm{S} 1$ in Additional file 1). IL-4 did suppress IL-17 production in vitro, albeit not to the extent seen in healthy controls. Comparing the RA groups, the extent of suppression of IL-17 production by IL-4 was intermediate and appeared to be similar among all genotype groups (Figure S2 in Additional file 1).

\section{Enumeration of Th17+ cells}

We also performed intracellular staining of cultured cells for both IL-17 and IFN- $\gamma$ and examined the samples by flow cytometry. A set of representative flow cytometry histograms is shown in Figure 3 for each of the healthy control group genotypes. There was a more pronounced suppression of the percentage of $\mathrm{IL}-17^{+}$ cells in the I/I genotype culture, as shown in the top row of Figure 3A, compared to the suppression of IL- $17^{+}$ cells in the $\mathrm{V} / \mathrm{V}$ genotype culture, shown in the bottom row. In these cultures, the majority of $\mathrm{IL}-17^{+}$cells were $\mathrm{CD} 4^{+}$, but some CD4-IL- $17^{+}$cells were also observed. IL-4 likewise affected the expression of IL-17 by these CD4 cells. Flow cytometry of cultured PBMCs activated under Th17 conditions showed that RA patients generated a higher percentage of $\mathrm{IL}-17^{+}$and $\mathrm{IL}-17^{+} / \mathrm{IFN} \gamma^{+}$ (Th1/Th17) cells compared to controls (Figure 3B). A large proportion of the Th17 cells in both healthy individuals and patients with RA are of dual Th17/Th1 lineage. IL-4 generally reduced the number of $\mathrm{IL}-17^{+} / \mathrm{IFN} \gamma^{+}$cells in parallel with reductions in the number of $\mathrm{IL}^{-17^{+}} / \mathrm{IFN} \gamma^{-}$ cells (data not shown).

\section{IL-17 concentrations in serum}

Consistent with in vitro generation of higher numbers of Th17 cells from RA mononuclear cells, we also observed higher serum IL-17 levels in the RA patients compared to the healthy individuals $(P=0.05)$ (Figure 4$)$. These results, as well as the flow cytometry data summarized in Figure 3, are consistent with a recent report that documents expansion of the Th17 subset in RA patients compared to healthy individuals [24].

\section{Discussion}

Several earlier studies supported a key role for IL-17 in the pathogenesis of RA [25]. Determining the regulatory mechanisms that could suppress Th17 cells might lead to novel approaches to the treatment of RA. In this study, we have examined the role of a single nucleotide polymorphism in the $I L-4 R$ in the control of IL-17 production.

The results indicate that a polymorphism in $I L-4 R$ in part controls production of IL-17 by Th17 cells cultured from healthy individuals. Specifically, IL-4 significantly inhibited IL-17 production by cells from subjects with the $\mathrm{I} / \mathrm{I}$ genotype $(P=0.0079)$ and the $\mathrm{I} / \mathrm{V}$ genotype $(P=$ $0.013)$, but not the $\mathrm{V} / \mathrm{V}$ genotype. An earlier study showed an association between two copies of the V50 allele and the rapid development of radiographic erosive disease [21]. That report also identified functional effects of the $I L-4 R$ polymorphism pertinent to Th1 and Th2 cells. With the recent accumulation of information regarding Th17 cells and RA [25], demonstration of a functional impact of the $I L-4 R$ polymorphism on IL-17 secretion provides further mechanistic insight that could be pertinent to the genetic control of RA severity.

There were several limitations to our current study. The healthy control and RA groups were not precisely matched by age or sex. The in vitro data derived from 
A.
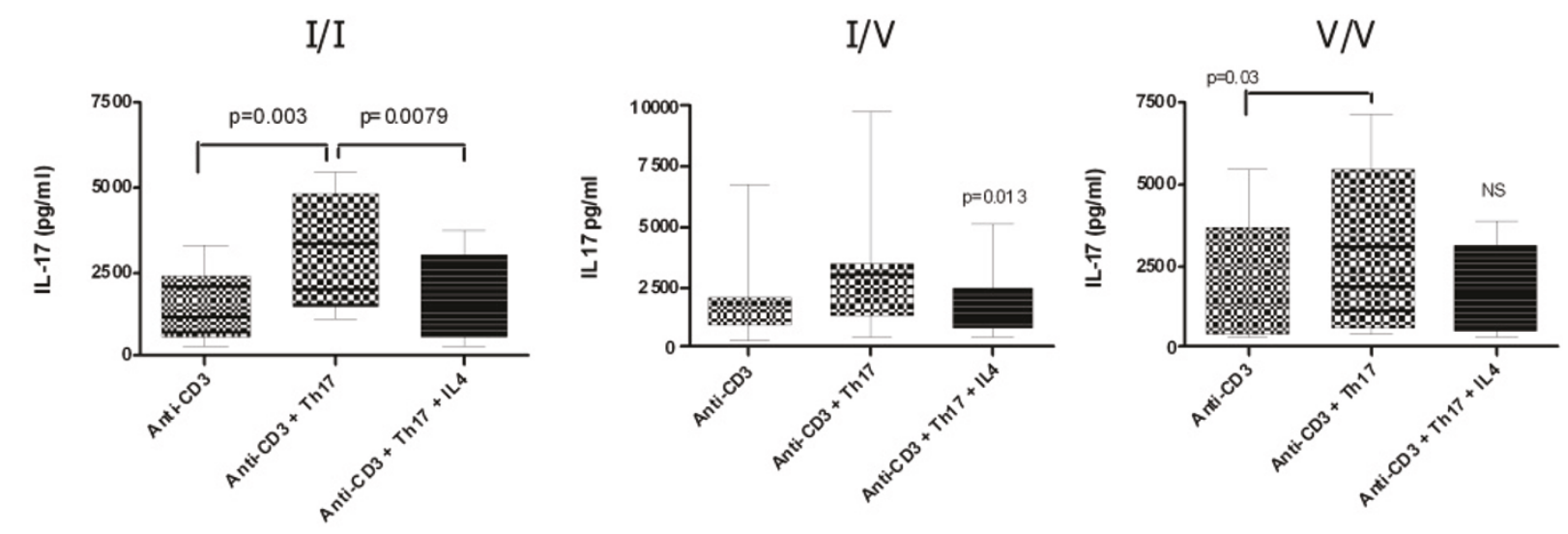

B.

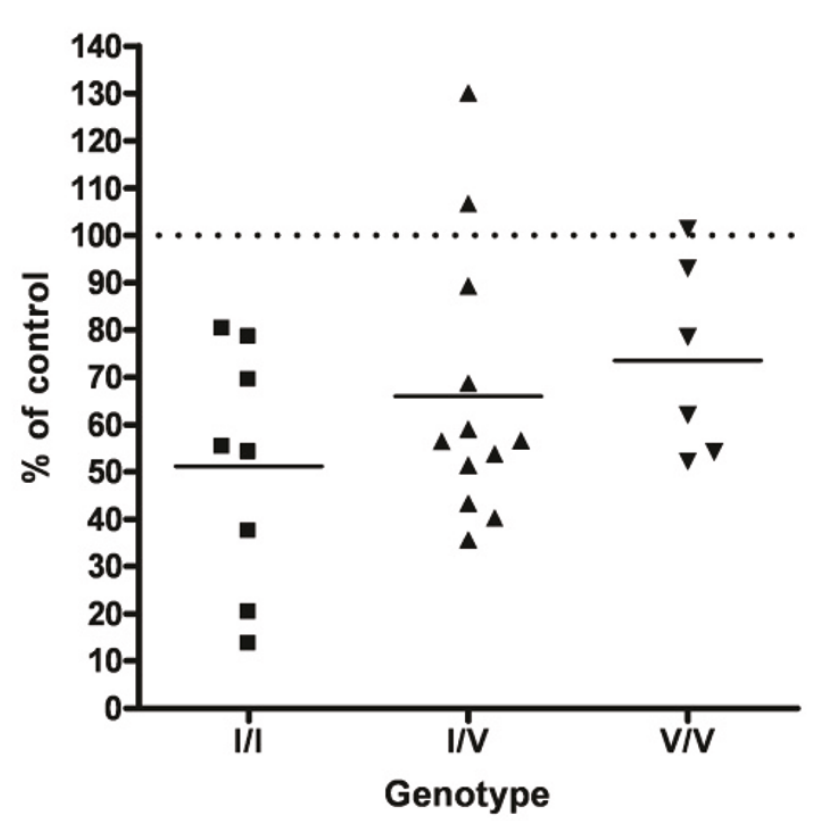

Figure 2 Inhibition of interleukin (IL)-17 production by IL-4: effect of IL-4R genotype. (A) Healthy control group IL-17 measured by enzyme-linked immunosorbent assay (ELISA) of culture supernatants. Comparison of Th17 conditions with or without IL-4: I/I, $P=0.0079 ; 1 \mathrm{~N}, P=$ $0.0013 ; \mathrm{VN}, P=$ NS. Paired comparisons were performed using a two-tailed $t$-test. (B) Proportion of IL-17 inhibition by IL-4. Assuming $100 \%$ to be the maximal IL-17 production (measured by ELISA) in supernatants of cultures containing anti-CD3 and Th17 stimulatory conditions, the percentage change from baseline after the addition of IL-4 to cultures of peripheral blood mononuclear cells is shown. I, isoleucine; V, valine.

the RA patient group is subject to selection bias due to referral of refractory RA patients to a tertiary center, and this is reflected in the greater prevalence of the V50 allele in this RA sample compared to previous results [21]. The clinical measurements in our patients provide a trend consistent with a previous report that the $I L-4 R$ is an important severity gene in RA [21]. However, the small sample size precludes any robust claims and points to the need for additional large longitudinal studies of cohorts of patients with early RA.

One study has failed to confirm an association of the I50V polymorphism with RA severity [26]. However, 


\section{A.}
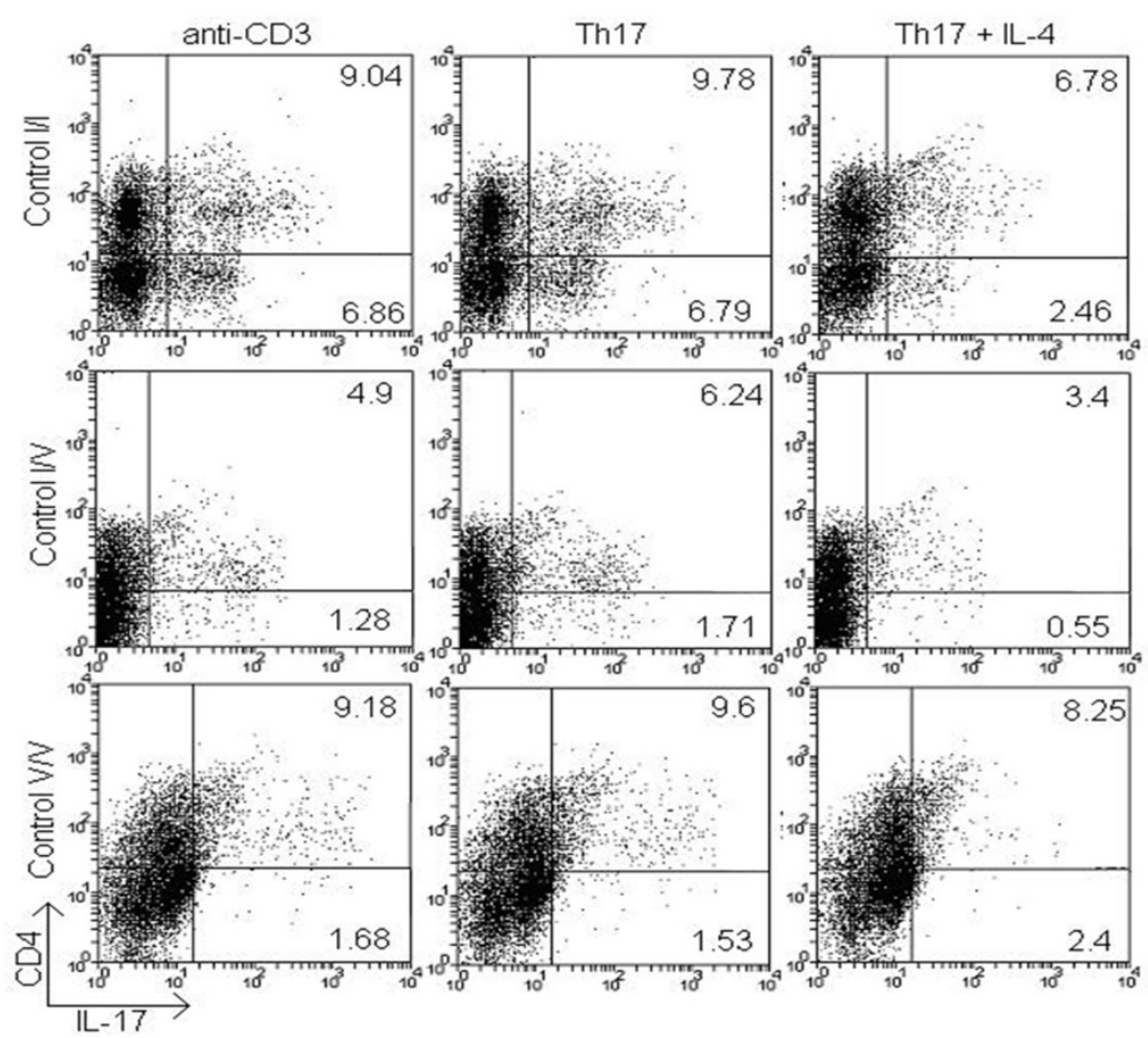

B.

\section{Total patient vs control}

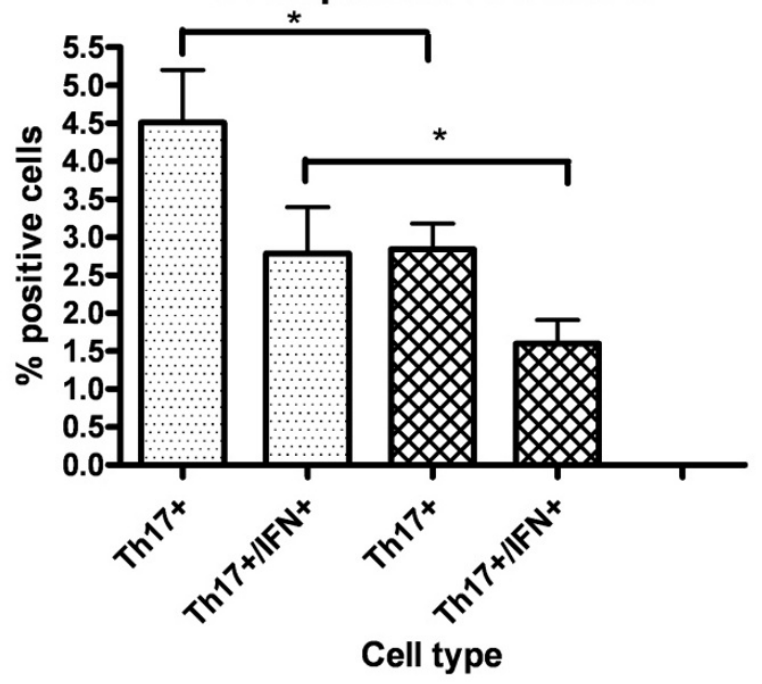

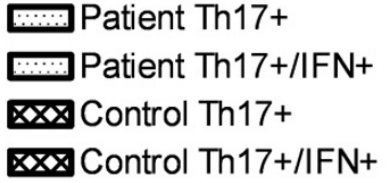

खx Control Th17+/IFN+

Figure 3 Flow cytometric enumeration of Th17 cells following a 5-day culture of peripheral blood mononuclear cells (PBMCs) (A) Representative flow cytometry histograms showing control PBMCs stained for CD4 and interleukin (IL)-17A after stimulation with anti-CD3, anti-CD3 and Th17 stimulatory conditions and anti-CD3 and Th17 stimulatory conditions with IL4. Numbers in quadrants represent the percentage of total cells expressing IL-17A. (B) Th17 and Th17/Th1 cell numbers generated in RA patient and control cultures. The difference between each cell type was statistically significant, $P<0.05$, comparing the patient and control groups. I, isoleucine; $V$, valine. 


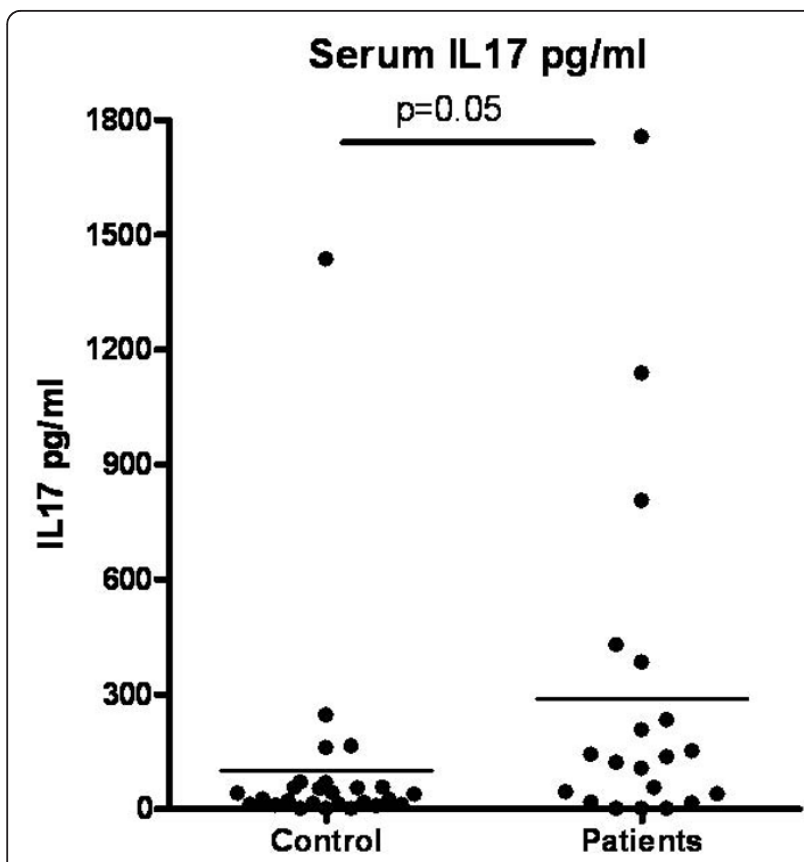

Figure 4 In vivo interleukin (IL)-17 production in healthy individuals and RA patients. Comparison of control and RA serum IL-17 levels, $P=0.05$.

this was a cross-sectional study in which participants had radiographs performed after various durations of RA. Severity was not calculated on the basis of the rate of accumulation of joint damage over a specific interval of time, and therefore an effect of I50V on severity may have been overlooked.

The pattern of IL-17 suppression seen in the healthy individuals was not replicated in the RA patients, potentially because of confounding effects of the various medications. A particularly interesting alternative (but not mutually exclusive) explanation is that in established RA Th17 cells become relatively refractory to IL-4, as we have observed in established CIA [16]. To better assess this possibility, it will be necessary to perform longitudinal studies of $I L-4 R$ genotype and IL-4-mediated regulation of IL-17 in a cohort of early-onset RA patients.

Allelic variation may lead to either gain or loss of function through the IL-4R. Several prior studies have found that receptors containing isoleucine at position 50 , compared with receptors containing valine at the same position, support increased signaling as measured by signal transducer and transactivator 6 phosphorylation [21,27-29]. The precise mechanism for this effect is not yet understood.

Although there is growing evidence for the importance of IL-4 in regulation of IL-17 production, the role that IL-4 plays in controlling inflammation and bone destruction extends beyond regulation of Th17 cells.
IL-4 is antiangiogenic [30], and intra-articular injections of the $I L-4$ gene reduced synovial tissue vessel density, inflammation and bone destruction in rat and mouse models of arthritis [31,32]. IL-4 directly suppresses production of vascular endothelial growth factor by synovial fibroblasts [33]. It is not excluded, however, that some of the in vivo effects of IL-4 on synovial angiogenesis are due to inhibition of IL-17 production in the synovium, with consequent downregulation of local production of proangiogenic mediators.

Other studies have pointed to a direct role for IL- 4 in regulation of tissue destruction in arthritis. IL-4 inhibits the spontaneous and stimulated production of matrix metalloproteinase 1 by synoviocytes [34]. While IL-17 is pro-osteoclastogenic in arthritis [35-37], IL-4 and IL-13 inhibit osteoclastic differentiation by activation of receptors that decrease RANK formation and by activation of receptors on osteoblasts that decrease RANKL expression but increase osteoprotegerin formation [36,38]. In an animal model of osteoarthritis, intra-articular injection of IL-4 inhibits chondrocyte production of nitric oxide and subsequent cartilage destruction [39]. IL-4 may also have suppressive effects on macrophage proliferation [40] and cytokine production [41].

\section{Conclusions}

The data in the present study suggest that a SNP in $I L-4 R$ confers a hypofunctional receptor that results in decreased inhibition of IL-17 by IL-4, which may allow unrestricted IL-17-mediated inflammation. IL-4 modulates inflammation and joint damage through various mechanisms, including those discussed here, and an attractive topic for future investigation is the effect of this SNP on the ability of IL-4 to regulate pathogenic behavior of cells other than $\mathrm{CD} 4^{+}$Th17 lymphocytes. Genotyping for V50 substitutions in the IL-4R may help identify those patients who are at the greatest risk for inflammation and tissue destruction in RA and who would therefore be the most suitable candidates for aggressive therapy, but this hypothesis requires validation in a prospective study of early RA patients. Approaches that regulate Th17 cells or neutralize their products are under evaluation in the treatment of RA and may be particularly attractive for patients in whom endogenous mechanisms for control of Th17 cells are demonstrably inadequate.

\section{Additional material}

Additional file 1: Table S1, Supplemental Figures S1 and S2. Table S1. Baseline characteristics of study patients. Figure S1. Regulation of interleukin-17 production in vitro. Figure S2. Inhibition of interleukin (IL)17 production by IL-4: effect of IL-4R genotype in rheumatoid arthritis patients. 


\section{Abbreviations}

APC: antigen-presenting cell; CIA: collagen-induced arthritis; DMARDS: disease-modifying antirheumatic drugs; IFN- $\gamma$ : interferon- $\gamma$; IL: interleukin; MMP: matrix metalloproteinase; NCS: newborn calf serum; PBMC: peripheral blood mononuclear cells; PBS: phosphate-buffered saline; PCR: polymerase chain reaction; PMA: phorbol myristate acetate; RA: rheumatoid arthritis; RANKL: receptor activator of NF-KB ligand; SNP: single-nucleotide polymorphism; STAT: signal transducer and transactivator; TNF: tumor necrosis factor.

\section{Acknowledgements}

This work was supported by grants from the Arthritis Foundation and by National Institute of Arthritis and Musculoskeletal and Skin Diseases grant AR38477.

\section{Authors' contributions}

SW participated in study design, performed most of the experiments and drafted the manuscript. LC contributed to study design, optimization of methods, data interpretation and revision of the manuscript. JE supervised implementation of methods and data collection. MJL performed ELISA assays and flow cytometry. JR performed ELISA assays and flow cytometry. ES contributed to study design and performed statistical analysis. DF directed the study design and interpretation of the data and edited the manuscript.

\section{Competing interests}

The authors declare that they have no competing interests.

Received: 12 August 2010 Revised: 8 December 2010 Accepted: 4 February 2011 Published: 4 February 2011

\section{References}

1. Harrington LE, Hatton RD, Mangan PR, Turner H, Murphy TL, Murphy KM, Weaver CT: Interleukin 17-producing $\mathrm{CD}^{+}$effector T cells develop via a lineage distinct from the $\mathrm{T}$ helper type 1 and 2 lineages. Nat Immunol 2005, 6:1123-1132

2. $\quad$ Park H, Li Z, Yang $X O$, Chang $S H$, Nurieva $R$, Wang $Y H$, Wang $Y$, Hood L, Zhu Z, Tian Q, Dong C: A distinct lineage of CD4 T cells regulates tissue inflammation by producing interleukin 17. Nat Immunol 2005 6:1133-1141

3. Langrish CL, Chen Y, Blumenschein WM, Mattson J, Basham B, Sedgwick JD, McClanahan T, Kastelein RA, Cua DJ: IL-23 drives a pathogenic T cell population that induces autoimmune inflammation. J Exp Med 2005 201:233-240.

4. Cua DJ, Sherlock J, Chen Y, Murphy CA, Joyce B, Seymour B, Lucian L, To W, Kwan S, Churakova T, Zurawski S, Wiekowski M, Lira SA, Gorman D, Kastelein RA, Sedgwick JD: Interleukin-23 rather than interleukin-12 is the critical cytokine for autoimmune inflammation of the brain. Nature 2003, 421:744-748.

5. Murphy $C A$, Langrish $C L$, Chen $Y$, Blumenschein W, McClanahan T, Kastelein RA, Sedgwick JD, Cua DJ: Divergent pro- and antiinflammatory roles for IL-23 and IL-12 in joint autoimmune inflammation. J Exp Med 2003, 198:1951-1957.

6. Bettelli E, Carrier Y, Gao W, Korn T, Strom TB, Oukka M, Weiner HL, Kuchroo VK: Reciprocal developmental pathways for the generation of pathogenic effector TH17 and regulatory T cells. Nature 2006, 441:235-238.

7. Mangan PR, Harrington LE, O'Quinn DB, Helms WS, Bullard DC, Elson CO, Hatton RD, Wahl SM, Schoeb TR, Weaver CT: Transforming growth factor- $\beta$ induces development of the $T_{H} 17$ lineage. Nature 2006, 441:231-234.

8. Veldhoen M, Hocking RJ, Atkins CJ, Locksley RM, Stockinger B: TGF $\beta$ in the context of an inflammatory cytokine milieu supports de novo differentiation of IL-17-producing T cells. Immunity 2006, 24:179-189.

9. Wilson NJ, Boniface K, Chan JR, McKenzie BS, Blumenschein WM, Mattson JD, Basham B, Smith K, Chen T, Morel F, Lecron JC, Kastelein RA, Cua DJ, McClanahan TK, Bowman EP, de Waal Malefyt R: Development, cytokine profile and function of human interleukin 17-producing helper T cells. Nat Immunol 2007, 8:950-957.

10. Acosta-Rodriguez EV, Napolitani G, Lanzavecchia A, Sallusto F: Interleukins $1 \beta$ and 6 but not transforming growth factor- $\beta$ are essential for the differentiation of interleukin 17-producing human T helper cells. Nat Immunol 2007, 8:942-949.

11. Tesmer LA, Lundy SK, Sarkar S, Fox DA: Th17 cells in human disease. Immunol Rev 2008, 223:87-113.

12. Weaver CT, Harrington LE, Mangan PR, Gavrieli M, Murphy KM: Th17: an effector CD4 T cell lineage with regulatory T cell ties. Immunity 2006, 24:677-688.

13. Korn T, Bettelli E, Oukka M, Kuchroo VK: IL-17 and Th17 Cells. Annu Rev Immunol 2009, 27:485-517.

14. Myers LK, Tang B, Stuart JM, Kang AH: The role of IL-4 in regulation of murine collagen-induced arthritis. Clin Immunol 2002, 102:185-191.

15. Morita Y, Yang J, Gupta R, Shimizu K, Shelden EA, Endres J, Mule JJ, McDonagh KT, Fox DA: Dendritic cells genetically engineered to express IL-4 inhibit murine collagen-induced arthritis. J Clin Invest 2001, 107:1275-1284

16. Sarkar S, Tesmer LA, Hindnavis V, Endres JL, Fox DA: Interleukin-17 as a molecular target in immune-mediated arthritis: immunoregulatory properties of genetically modified murine dendritic cells that secrete interleukin-4. Arthritis Rheum 2007, 56:89-100.

17. Kim SH, Bianco NR, Shufesky WJ, Morelli AE, Robbins PD: Effective treatment of inflammatory disease models with exosomes derived from dendritic cells genetically modified to express IL-4. J Immunol 2007, 179:2242-2249.

18. Skapenko A, Wendler J, Lipsky PE, Kalden JR, Schulze-Koops H: Altered memory $T$ cell differentiation in patients with early rheumatoid arthritis. J Immunol 1999, 163:491-499.

19. Kruse S, Japha T, Tedner M, Sparholt SH, Forster J, Kuehr J, Deichmann KA The polymorphisms S503P and Q576R in the interleukin-4 receptor a gene are associated with atopy and influence the signal transduction. Immunology 1999, 96:365-371.

20. Risma KA, Wang N, Andrews RP, Cunningham CM, Ericksen MB, Bernstein JA, Chakraborty R, Hershey GK: V75R576 IL-4 receptor a is associated with allergic asthma and enhanced IL-4 receptor function. J Immunol 2002, 169:1604-1610.

21. Prots I, Skapenko A, Wendler J, Mattyasovszky S, Yone CL, Spriewald B, Burkhardt H, Rau R, Kalden JR, Lipsky PE, Schulze-Koops H: Association of the IL4R single-nucleotide polymorphism I50V with rapidly erosive rheumatoid arthritis. Arthritis Rheum 2006, 54:1491-1500.

22. Grigor C, Capell H, Stirling A, McMahon AD, Lock P, Vallance R, Kincaid W, Porter D: Effect of a treatment strategy of tight control for rheumatoid arthritis [the TICORA study]: a single-blind randomised controlled trial. Lancet 2004, 364:263-269.

23. Goekoop-Ruiterman YP, de Vries-Bouwstra JK, Allaart CF, van Zeben D, Kerstens PJ, Hazes JM, Zwinderman AH, Ronday HK, Han KH, Westedt ML, Gerards AH, van Groenendael JH, Lems WF, van Krugten MV, Breedveld FC, Dijkmans BA: Clinical and radiographic outcomes of four different treatment strategies in patients with early rheumatoid arthritis [the BeSt study]: a randomized, controlled trial. Arthritis Rheum 2008, 58:S126-S135.

24. Leipe J, Grunke M, Dechant C, Reindl C, Kerzendorf U, Schulze-Koops H, Skapenko A: Role of Th17 cells in human autoimmune arthritis. Arthritis Rheum 2010, 62:2876-2885.

25. Sarkar S, Cooney LA, Fox DA: The role of T helper type 17 cells in inflammatory arthritis. Clin Exp Immunol 2010, 159:225-237.

26. Marinou I, Till SH, Moore DJ, Wilson AG: Lack of association or interactions between the IL-4, IL-4a and IL-13 genes, and rheumatoid arthritis. Arthritis Res Ther 2008, 10:R80.

27. Stephenson L, Johns MH, Woodward E, Mora AL, Boothby M: An IL-4Ra allelic variant, 150, acts as a gain-of-function variant relative to V50 for Stat6, but not Th2 differentiation. J Immunol 2004, 173:4523-4528.

28. Mitsuyasu H, Yanagihara $Y$, Mao XQ, Gao PS, Arinobu Y, Ihara K, Takabayashi A, Hara T, Enomoto T, Sasaki S, Kawai M, Hamasaki N, Shirakawa T, Hopkin JM, Izuhara K: Cutting edge: dominant effect of Ile50Val variant of the human IL-4 receptor a-chain in IgE synthesis. J Immunol 1999, 162:1227-1231.

29. Yabiku K, Hayashi M, Komiya I, Yamada T, Kinjo Y, Ohshiro Y, Kouki T, Takasu N: Polymorphisms of interleukin [IL]-4 receptor alpha and signal transducer and activator of transcription-6 [Stat6] are associated with increased IL-4Ra-Stat6 signalling in lymphocytes and elevated serum IgE in patients with Graves' disease. Clin Exp Immunol 2007, 148:425-431.

30. Szekanecz Z, Koch AE: Angiogenesis and its targeting in rheumatoid arthritis. Vascul Pharmacol 2009, 51:1-7. 
31. Haas CS, Amin MA, Allen BB, Ruth JH, Haines GK, Woods JM, Koch AE: Inhibition of angiogenesis by interleukin-4 gene therapy in rat adjuvantinduced arthritis. Arthritis Rheum 2006, 54:2402-2414.

32. Lubberts $E$, Joosten $L A$, van Den Bersselaar $L$, Helsen MM, Bakker AC, van Meurs JB, Graham FL, Richards CD, van Den Berg WB: Adenoviral vectormediated overexpression of IL-4 in the knee joint of mice with collageninduced arthritis prevents cartilage destruction. J Immunol 1999, 163:4546-4556.

33. Hong KH, Cho ML, Min SY, Shin YJ, Yoo SA, Choi JJ, Kim WU, Song SW, Cho CS: Effect of interleukin-4 on vascular endothelial growth factor production in rheumatoid synovial fibroblasts. Clin Exp Immunol 2007, 147:573-579.

34. Chabaud M, Garnero P, Dayer JM, Guerne PA, Fossiez F, Miossec P: Contribution of interleukin 17 to synovium matrix destruction in rheumatoid arthritis. Cytokine 2000, 12:1092-1099.

35. Kotake S, Udagawa N, Takahashi N, Matsuzaki K, Itoh K, Ishiyama S, Saito S, Inoue K, Kamatani N, Gillespie MT, Martin TJ, Suda T: IL-17 in synovial fluids from patients with rheumatoid arthritis is a potent stimulator of osteoclastogenesis. J Clin Invest 1999, 103:1345-1352.

36. Yamada A, Takami M, Kawawa T, Yasuhara R, Zhao B, Mochizuki A, Miyamoto Y, Eto T, Yasuda H, Nakamichi Y, Kim N, Katagiri T, Suda T, Kamijo R: Interleukin-4 inhibition of osteoclast differentiation is stronger than that of interleukin-13 and they are equivalent for induction of osteoprotegerin production from osteoblasts. Immunology 2007. 120:573-579.

37. Koenders MI, Lubberts E, Oppers-Walgreen B, van den Bersselaar L, Helsen MM, Di Padova FE, Boots AM, Gram H, Joosten LA, van den Berg WB: Blocking of interleukin-17 during reactivation of experimental arthritis prevents joint inflammation and bone erosion by decreasing RANKL and interleukin-1. Am J Pathol 2005, 167:141-149.

38. Palmqvist $P$, Lundberg $P$, Persson $E$, Johansson $A$, Lundgren I, Lie $A$, Conaway HH, Lerner UH: Inhibition of hormone and cytokine-stimulated osteoclastogenesis and bone resorption by interleukin- 4 and interleukin13 is associated with increased osteoprotegerin and decreased RANKL and RANK in a STAT6-dependent pathway. J Biol Chem 2006, 281:2414-2429.

39. Yorimitsu M, Nishida K, Shimizu A, Doi H, Miyazawa S, Komiyama T, Nasu Y, Yoshida A, Watanabe S, Ozaki T: Intra-articular injection of interleukin-4 decreases nitric oxide production by chondrocytes and ameliorates subsequent destruction of cartilage in instability-induced osteoarthritis in rat knee joints. Osteoarthritis Cartilage 2008, 16:764-771.

40. Arpa L, Valledor AF, Lloberas J, Celada A: IL-4 blocks M-CSF-dependent macrophage proliferation by inducing p21Waf1 in a STAT6-dependent way. Eur J Immunol 2009, 39:514-526.

41. Cao Y, Brombacher F, Tunyogi-Csapo M, Glant TT, Finnegan A: Interleukin-4 regulates proteoglycan-induced arthritis by specifically suppressing the innate immune response. Arthritis Rheum 2007, 56:861-870.

doi:10.1186/ar3239

Cite this article as: Wallis et al: A polymorphism in the interleukin-4 receptor affects the ability of interleukin-4 to regulate Th17 cells: a possible immunoregulatory mechanism for genetic control of the severity of rheumatoid arthritis. Arthritis Research \& Therapy 2011 13:R15.

\section{Submit your next manuscript to BioMed Central and take full advantage of:}

- Convenient online submission

- Thorough peer review

- No space constraints or color figure charges

- Immediate publication on acceptance

- Inclusion in PubMed, CAS, Scopus and Google Scholar

- Research which is freely available for redistribution 